\title{
MICROSTRUCTURE AND PROPERTIES OF A TITANIUM CARBIDE REINFORCED COATING ON GREY IRON APPLIED WITH LASER CLADDING
}

\author{
MIKROSTRUKTURA IN LASTNOSTI S TITANOVIM KARBIDOM \\ OJAČANE PREVLEKE NA SIVI LITINI, IZDELANE Z LASERSKIM \\ PRETALJEVANJEM
}

\author{
Jieqiong Ding, Yanhui Liu*, Lingjie Zhu, Lei Zhou, Yongjiu Li \\ Shanghai University of Engineering Science, School of Materials Engineering, 333 Longteng Road, Songjiang District, Shanghai 201620, \\ China
}

Prejem rokopisa - received: 2018-09-22; sprejem za objavo - accepted for publication: 2018-12-17

doi:10.17222/mit.2018.206

\begin{abstract}
A titanium carbide $(\mathrm{TiC})$ reinforced Fe-based composite coating was prepared with laser cladding using titanium powder as the added material on grey cast iron. The macroscopic morphology and microstructure of the coating were analyzed; the hardness and wear resistance of the coating were investigated. The results show that a good coating was produced, without any cracks and porosity. The graphite phase disappeared and the TiC phase appeared in the coating after the laser-cladding process. A static melting zone without $\mathrm{TiC}$ and graphite appeared between the cladding zone and the substrate. With the formation of fine $\mathrm{TiC}$ particles, the average microhardness of the coating rose up by more than 3 times compared to the substrate material, and the coating exhibited good wear resistance.

Keywords: laser cladding, grey cast iron, TiC, wear resistance, coating
\end{abstract}

$\mathrm{S}$ titanovim karbidom (TiC) ojačan kompozit na osnovi Fe so avtorji pripravljali z laserskim pretaljevanjem in pri tem kot dodajni material uporabili Ti prah na podlagi iz sive litine. Analizirali so makro- in mikrostrukturo nastale prevleke ter določili njeno trdoto in odpornost proti obrabi. Rezultati kažejo, da so izdelali dobro prevleko brez razpok in poroznosti. Med laserskim pretaljevanjem je izginila grafitna faza in nastala je TiC faza. Statična talilna cona brez TiC in grafita se je pojavila med cono pretaljevanja in podlago. S tvorbo finih TiC delcev se je povprečna mikrotrdota prevlek v primerjavi s podlago iz sive litine povečala za več kot trikrat, prevleke pa so bile dobro odporne proti obrabi.

Ključne besede: lasersko pretaljevanje, siva litina, TiC, odpornost proti obrabi, prevleka

\section{INTRODUCTION}

Grey cast iron is widely used for engineering equipment with complex shapes, such as pistons and cylinders in the automotive industry, due to its excellent casting properties, excellent vibration-damping properties and low costs. ${ }^{1,2}$ However, flake graphite breaks the continuity and integrity of grey cast iron and leads to low toughness and low fatigue limits of grey cast iron. ${ }^{3-5}$

Laser cladding is an economic and efficient method for improving the quality and properties of the surface layers of engineering parts. ${ }^{67}$ Lin et al. ${ }^{8}$ produced a composite coating on vermicular graphite cast iron reinforced with $\mathrm{Al}_{2} \mathrm{O}_{3}$ particulates with selective laser surface cladding. Both the microhardness and strength of the composite coating were increased. The crack density was reduced according to the thermal-fatigue test. Zulhishamuddin et al. ${ }^{9}$ found that the laser-clad surface of grey cast iron with an addition of Mo and $\mathrm{Cr}$ exhibited a high hardness value of $945.5 \mathrm{HV}_{0.1}$ due to the carbide formation. Janicki et al. ${ }^{10}$ investigated the dry-sliding-

*Corresponding author e-mail:

Liuyanhui2017@163.com wear properties of a TiC-reinforced composite surface layer on a ductile cast-iron substrate. Following the ASTMG 99 standard test method under contact pressures of $2.12 \mathrm{MPa}$ and $4.25 \mathrm{MPa}$, the layer exhibited a significantly higher wear resistance than the substrate and the laser-surface-melted layers.

Secondary-phase strengthening and solution strengthening are the main mechanisms of laser cladding. Alumina $\left(\mathrm{Al}_{2} \mathrm{O}_{3}\right)$, silicon carbide $(\mathrm{SiC})$, titanium carbide (TiC) and tungsten carbide (WC) are commonly chosen as the secondary-phase particles. ${ }^{11,12}$ Among them, TiC has the following advantage for cast iron: it can be readily synthesized in a laser melt pool; thus, it significantly reduces the carbon content in the matrix. ${ }^{13-15}$ Janicki et al. ${ }^{14}$ found that the morphology and fraction of the TiC phase directly depends on the concentration of titanium in the melt pool and on the solidification rate. With an increased titanium content, the fraction of TiC increases, whereas the fraction of cementite decreases. The TiC phase promotes the heterogeneous nucleation of primary austenite grains, which reduce the tendency of cracking in cladding layers. Tong et al. ${ }^{15}$ produced a TiC/Co-based alloy with laser 
cladding on the surface of nodular-graphite cast iron. The cladding layer consisted of a surface layer of dendritic crystals and internal cellular crystals. The maximum hardness of the cladding layer was $1278.8 \mathrm{HV}_{0.2}$, up to 5 times more than the hardness of the nodulargraphite cast-iron matrix.

In this paper, we report on desiging and executing the laser-cladding processing of a grey cast iron surface in order to improve the surface quality and properties. Titanium powder was selected as the cladding powder for the synthesis of the TiC phase in a laser melt pool. Subsequently, the microstructure and hardness of the laser-clad coatings were investigated and measured. The influence of the laser-cladding processing on the geometric characteristic of the cladding channel is discussed.

\section{EXPERIMENTAL PART}

HT250 was selected as the substrate for laser cladding; the raw material was cut into a disk specimen with dimensions of $\Phi 50 \times 8 \mathrm{~mm}$. Pure titanium powder (a purity $=99.0 \%$ and a size of 200-300 mesh) was used as the cladding material. The titanium powder and the binder were mixed into a paste and put on the clean surface of the substrate. The thickness of the powder layer was about $1 \mathrm{~mm}$. Then the preset layer was dried at $80{ }^{\circ} \mathrm{C}$ for $30 \mathrm{~min}$ in an air drier.

The laser cladding processing was done using a YSL-5000 fiber laser with argon protection. The laser process parameters were as follows: a spot diameter of $5 \mathrm{~mm}$, a laser power of $3 \mathrm{KW}$ and scanning speeds of $10 \mathrm{~mm} \mathrm{~s}^{-1}, 15 \mathrm{~mm} \mathrm{~s}^{-1}$ and $20 \mathrm{~mm} \mathrm{~s}^{-1}$.

The laser-cladding specimen was cut and prepared as a metallographic sample. The polished cross-section of the laser-cladding channel was etched using $4 \%$ nitric acid alcohol. A Hitachi S3400 scanning electron microscope (SEM) and a Keyence VHK-600 optical digital microscope were used to observe the microstructure of the cladding layer. The phase composition and crystal structure of the coating were investigated using a Philips

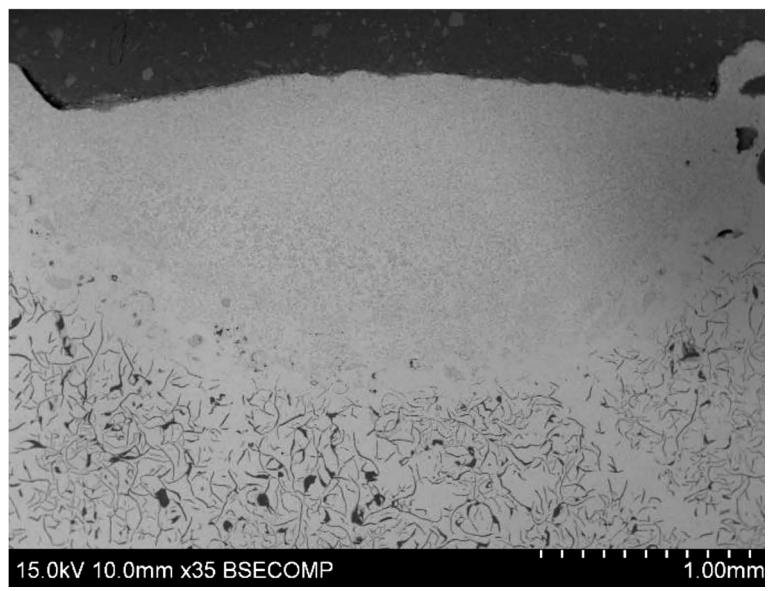

Figure 1: Macroscopic morphology of the channel melted with laser cladding
X'Pert Pro X-ray diffractometer (XRD); the goniometer's moving step was $0.02^{\circ}$ and the scanning-angle range was $10^{\circ}-90^{\circ}$. The microhardness was measured with a Shanghai Taiming's HX-1000 micro Vickers hardness tester. The test load was $1.96 \mathrm{~N}$ and the holding time was $15 \mathrm{~s}$. The microhardness was tested along the middle line of the cladding coating from the top to the substrate, at the cross-section and at a $0.10 \mathrm{~mm}$ step. The wear experiment was done using a Bruker UMT-3M-220 multi-functional friction and wear testing machine. The experiment load was $98 \mathrm{~N}$, the rotational speed was $100 \mathrm{r} \cdot \mathrm{min}^{-1}$, the wear-scar diameter was $4 \mathrm{~mm}$, the test time was $30 \mathrm{~min}$, the sport mode was the ball-disk type and the grinding head material was hard alloy steel.

\section{RESULTS AND DISCUSSION}

Figure 1 shows the cross-sectional morphology of the laser-clad coating on the grey-cast-iron surface. From a macroscopic view, the cross-section of the laser-cladding channel can be divided into four parts: the cladding zone, the transition zone, the heat-affected zone and the substrate. The maximum depth and the surface width of the cladding zone were measured using a Keyence VHK-600 microscope and their values are listed in Table 1, which indicates that the geometric shape of the cross-section of the cladding channel is affected by the laser scanning speed. Namely, with an increasing scanning speed, the maximum depth and the surface width of the cladding zone decrease because the energy input is reduced. In addition, the scanning speed has more influence on the surface width than on the maximum depth, which is related to the Gaussian model of the laser-beam energy and the heat-input feature. The surface width of the cladding channel depends on the combined contribution of the laser radiation and heat conduction. But the maximum depth of the cladding channel depends on the heat conduction only.

Figure 2 shows the XRD spectra of the cladding coating and the substrate. It is clear that diffraction peaks

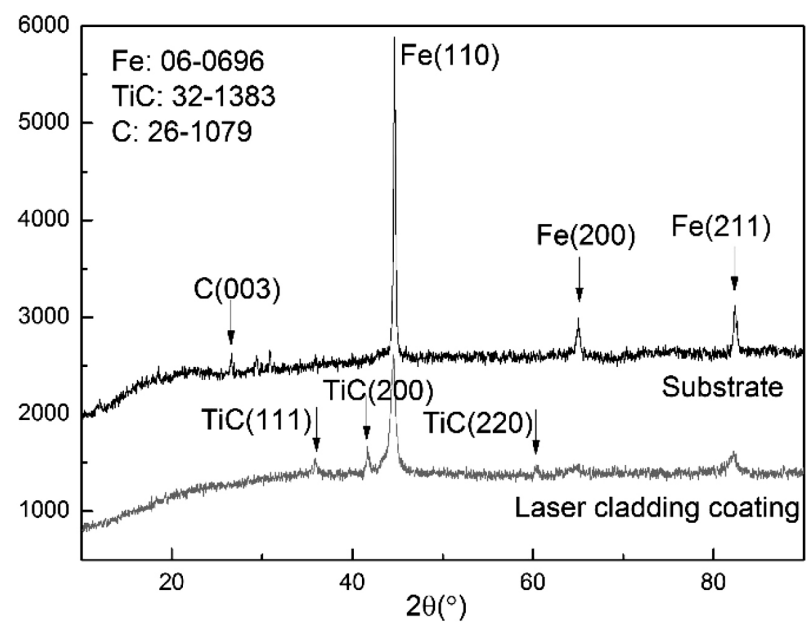

Figure 2: XRD spectra of the laser-cladding coating and the substrate 
of the TiC phase appear, whereas diffraction peaks of the graphite phase disappear in the cladding coating. In addition, diffraction peak of the $\alpha$-Fe phase is broadened. The XRD spectrum of the cladding coating indicates that the TiC phase was formed as the secondary phase and that the $\alpha$-Fe phase was alloyed with the matrix during the laser cladding.

Table 1: Geometrical dimensions of the laser-cladding channel

\begin{tabular}{|c|c|c|c|}
\hline Laser scanning speed $\left(\mathrm{mm} \cdot \mathrm{s}^{-1}\right)$ & 10 & 15 & 20 \\
\hline Depth $(\mathrm{mm})$ & 2.15 & 1.87 & 1.86 \\
\hline Width $(\mathrm{mm})$ & 5.2 & 4.23 & 3.85 \\
\hline
\end{tabular}

Figure 3 shows the microstructures of the lasercladding channel cross-sections. According to the EDS-analysis results from Table 2, the black particle phase is TiC in Figures 3a, b and $\mathbf{c}$ (the laser-cladding zone). This is in agreement with the principle of backscattered electron imaging: the lower is the average atomic number, the darker is the color. Table 2 also indicates that the grey matrix is the $\alpha$-Fe phase in the laser-cladding zone. Figure 3 exhibits the grain shape of the $\alpha$-Fe phase, changing from an equiaxed shape in Figures $\mathbf{3 a}$ and $\mathbf{3 b}$ to a columnar shape in Figures 3c and $\mathbf{3 d}$, to acicular martensite in Figure 3e (the heataffected zone) and to lamellar pearlite in Figure $3 \mathbf{f}$ (the substrate). ${ }^{16,17}$ In addition, the morphology and site indicate that the black phase in Figures 3d, 3e and $\mathbf{3 f}$ is flake graphite.

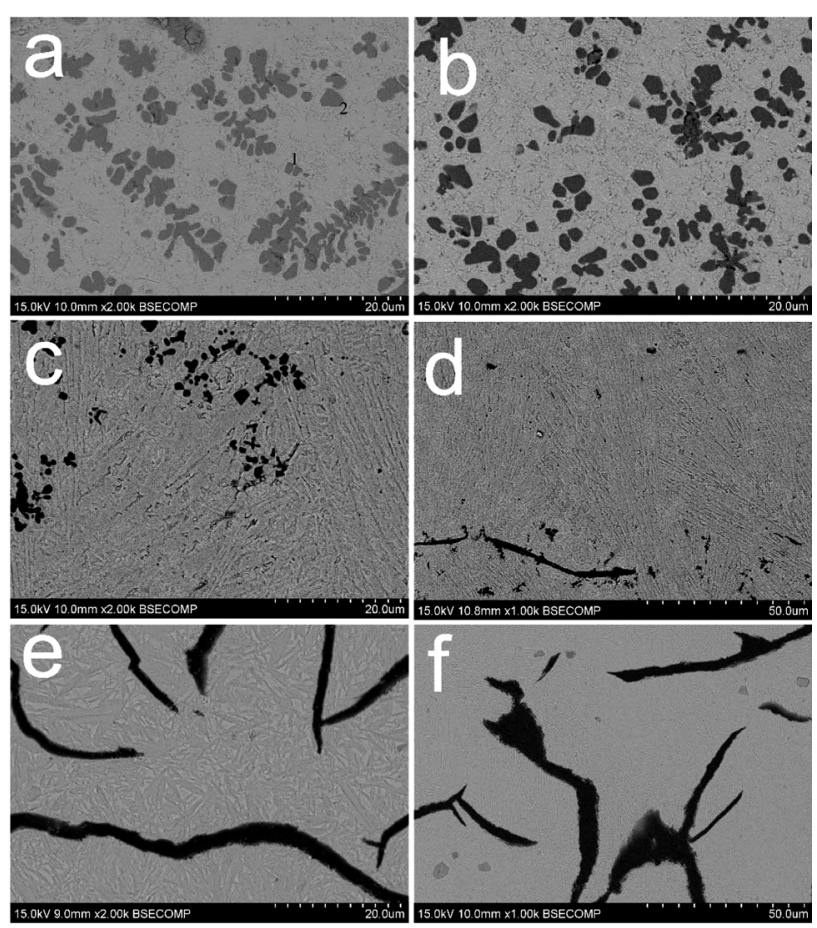

Figure 3: Microstructure of the laser-cladding coating: a) channel top, b) channel middle, c) channel bottom, d) transition zone (static melting zone), e) heat-affected zone and f) substrate
Table 2: Results of the EDS point analysis from Figure 3a (atomic number fraction, \%)

\begin{tabular}{|c|c|c|c|c|}
\hline Point & $\mathrm{C}$ & $\mathrm{Si}$ & $\mathrm{Ti}$ & $\mathrm{Fe}$ \\
\hline 1 & 43.35 & - & 54.88 & 1.77 \\
\hline 2 & 0.95 & 4.34 & 5.75 & 88.96 \\
\hline
\end{tabular}

Different morphologies of $\mathrm{TiC}$, graphite and $\alpha$-Fe phase demonstrate the laser-cladding effect. The $\mathrm{TiC}$ particles are granular and petaline with a size of about several micrometers, as seen in Figures $\mathbf{3 a}$ and $\mathbf{3 b}$. However, in Figure 3c, the TiC particles are smaller and scarcer. This means that the TiC crystals nucleate at the bottom of the laser melt pool, while graphite particles rise and encounter melted titanium atoms via the Marangoni convection and buoyancy force. After that, the TiC crystals grow up in the direction opposite of that of the heat transfer.

The distribution of TiC, graphite and $\alpha$-Fe phase with different morphologies also divides the laser melt pool into two parts: the convective cladding zone (Figures 3a and $\mathbf{3 b}$ ) and static melting zone (Figures $\mathbf{3 c}$ and $\mathbf{3 d}$ ). The static melting zone contains no $\mathrm{TiC}$ or graphite because there is no convection and the melted titanium atoms cannot get in due to thermal diffusion. The graphite rises up with the buoyancy force. The shape of $\alpha$-Fe in Figures $3 \mathbf{c}$ and $\mathbf{3 d}$ confirms the existence of the static melting zone as the grains are spindly columnar and the growth direction has the typical characteristic of directional heat dissipation. ${ }^{16}$ The acicular martensite and graphite in Figure 3e confirm that laser cladding leads to a formation of quenched martensite in the heat-affected zone. Since acicular martensite increases the brittleness, it should be eliminated with the preheating process.

Figure 4 shows the microhardness profile of the laser-cladding coating at different scanning speeds. The average microhardness of the laser cladding coating is about $650 \mathrm{HV}$ and the microhardness value of the coating fluctuates between 400-800 HV. The microhardness of grey cast iron is about $200 \mathrm{HV}$. This means that

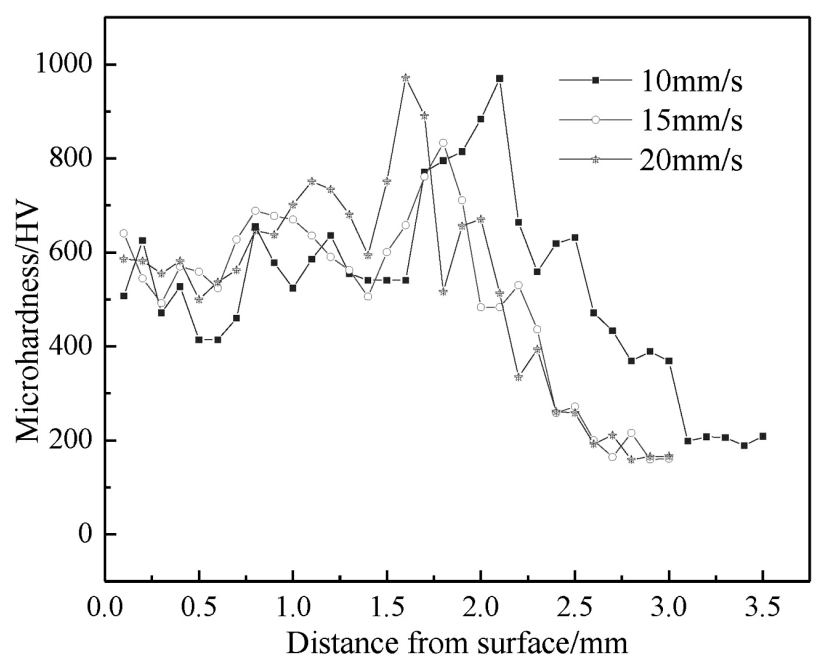

Figure 4: Hardness of the coating at different laser scanning speeds 

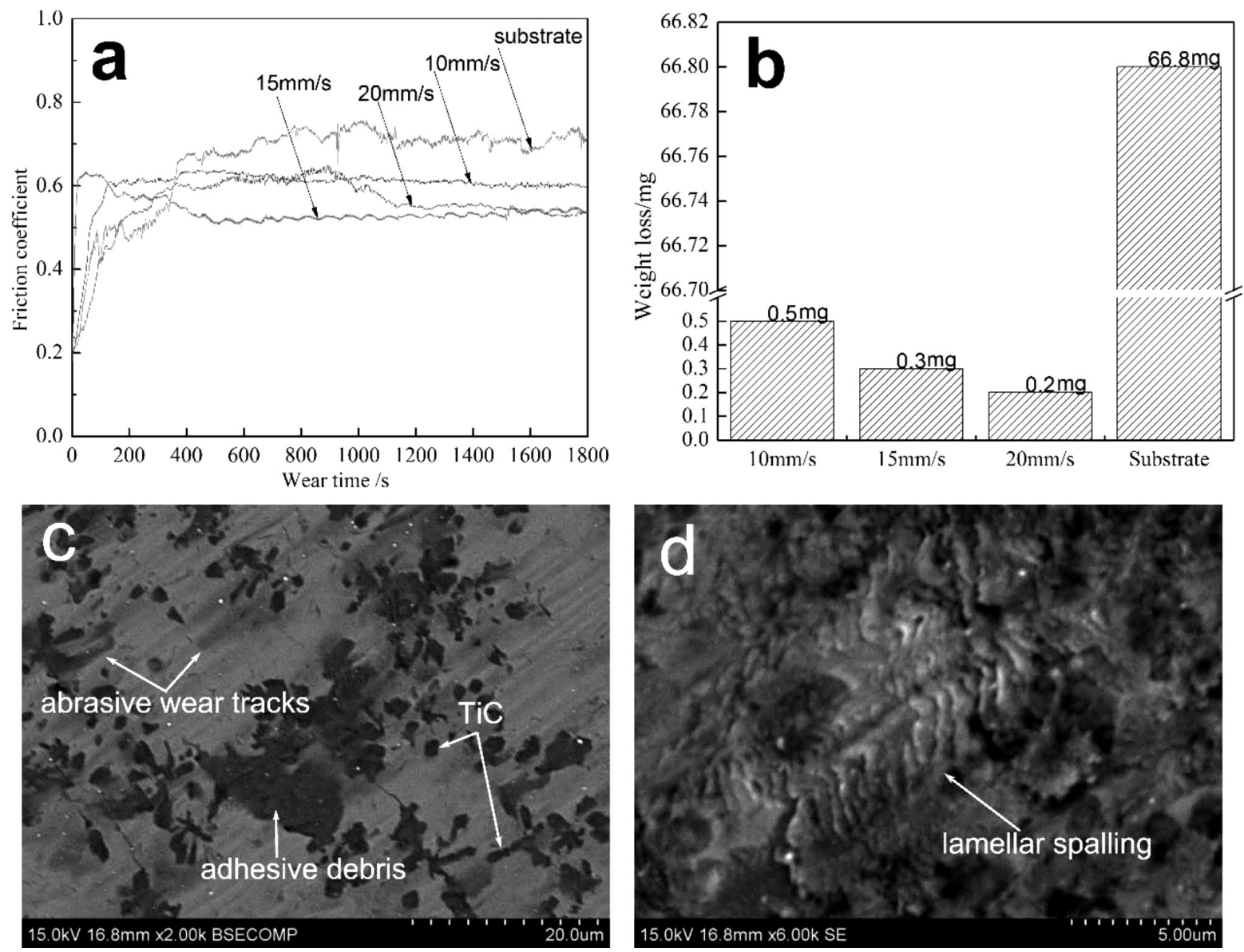

Figure 5: Wear experiment results reveal a) friction coefficient, b) wear weight loss, c) BSE image of the wear-scar microstructure and d) wear-scar morphology

the surface hardness of grey cast iron is improved by more than 3 times.

The enhancement of the surface hardness is due to the high hardness of $\mathrm{TiC}$ and a uniform and fine microstructure obtained with the rapid solidification. In addition, the maximum microhardness of the heat-affected zone rises up to $1000 \mathrm{HV}$, close to the bonding line, because of the coarse acicular martensite. The microhardness gradually drops with the reduction in the grain size and the amount of acicular martensite toward the substrate. It should be noted that the scanning speed does not have a significant influence on the hardness of the laser-cladding coating in Figure 4. However, it affects the coating thickness.

Figure 5 exhibits the wear resistance of the lasercladding coating on the surface of grey cast iron. Figure 5a shows the friction-coefficient curves of coating made at different laser scanning speeds, compared to the pure substrate. It is clear that the coating stabilizes the wear stage quicker than the substrate. The average friction coefficient of the coating is lower than that of the substrate. Figure 5b shows that the weight loss of the coating is far lower than that of the substrate. The main reasons for this are the high hardness of the laser-cladd- ing coating and the wear resistance of the TiC particles in the coating. SEM images of the wear scar are in good agreement with the above data, see Figures $\mathbf{5 c}$ and $\mathbf{5 d}$. Figure 5c shows that the adhesive and abrasive wear appear on the coating, whereas Figure 5d reveals lamellar spalling on the wear surface. But the abrasive-wear line is light and short because of the reinforcement effect of the TiC particles on the coating.

\section{CONCLUSIONS}

A grey-cast-iron surface is strengthened with laser cladding using titanium powder as the addition. The experiment results show that a TiC-reinforced Fe-based composite coating was produced on the grey-cast-iron surface. A good coating without any cracks and porosity is obtained. The laser scanning speed influences the geometric characteristic of the cross-section of the laser-cladding channel.

The XRD spectrum and SEM image confirm that the graphite phase disappears and the TiC phase appears in the coating after the laser-cladding process. The fine $\mathrm{TiC}$ particles are uniformly distributed in the cladding zone. The static melting zone, formed between the cladding 


\section{J. DING et al.: MICROSTRUCTURE AND PROPERTIES OF A TITANIUM CARBIDE REINFORCED COATING ...}

zone and the substrate, contains no TiC and no graphite. The hardness and the wear resistance of the grey-castiron surface are significantly improved due to the high TiC hardness and rapid-solidification microstructure of the coating. The average hardness of the cladding zone is three times higher than that of the substrate. However, the highest hardness of the coating is found under the transition zone due to the coarse quenched martensite. It needs to be regulated using the preheating process.

\section{Acknowledgment}

This work was supported by the Shanghai Science and Technology Committee Innovation Grant (17JC1400600, 17JC1400601) and Graduate Students' Innovative Research Projects of Shanghai University of Engineering Science (17KY0513).

\section{REFERENCES}

${ }^{1}$ M. A. Azeem, M. K. Bjerre, R. C. Atwood, N. Tiedje, P. D. Lee, Synchrotron quantification of graphite nodule evolution during the solidification of cast iron, Acta Mater., 155 (2018), 393-401, doi:10.1016/j.actamat.2018.06.007

${ }^{2}$ M. A. Guitar, S. Suarez, O. Prat, M. D. Guigou, V. Gari, G. Pereira, F. Mucklich, High chromium cast irons: destabilized-subcritical secondary carbide precipitation and its effect on hardness and wear properties, J. Mater. Eng. Perform., 27 (2018), 3877-3885, doi:10.1007/s11665-018-3347-1

${ }^{3}$ Y. Z. Liu, J. D. Xing, Y. F. Li, S. G. Wang, D. Tao, Tomographical study of the effect of graphite on properties of cast iron, Steel Res. Int., 89 (2018) 8, UNSP 1800086, doi:10.1002/srin.201800086

${ }^{4}$ Y. J. Li, S. Y. Dong, S. X. Yan, X. T. Liu, P. He, B. S. Xu, Surface remanufacturing of ductile cast iron by laser cladding $\mathrm{Ni}-\mathrm{Cu}$ alloy coatings, Surf. Coat. Tech., 347 (2018), 20-28, doi:10.1016/ j.surfcoat.2018.04.065

${ }^{5}$ J. X. Liu, C. Ma, L. D. Yu, Y. Wang, Z. Y. Jiao, Remanufacturing of nodular cast iron crankshaft with plasma cladding, Adv. Mech. Eng., 10 (2018) 6, doi:10.1177/1687814018779852

${ }^{6}$ Y. S. Tian, C. Z. Chen, S. T. Li, Q. H. Huo, Research progress on laser surface modification of titanium alloys, Appl. Surf. Sci., 242 (2004) 1, 177-184, doi:10.1016/j.apsusc.2004.08.011
${ }^{7}$ J. Kusinski, S. Kac, A. Kopia, A. Radziszewska, M. Rozmus-Gornikowska, B. Major, L. Major, J. Marczak, A. Lisiecki, Laser modification of the materials surface layer - a review paper, B. Pol. Acad. Sci.-Tech., 60 (2012) 4, 711-728, doi:10.2478/v10175012-0083-9

${ }^{8}$ P. Y. Lin, Z. H. Zhang, S. H. Kong, H. Zhou, X. Tong, L. Q. Ren, Mechanical properties of composite coating on cast iron by laser, Surf. Eng., 23 (2016) 4, 289-295, doi:10.1080/02670844.2016. 1201367

${ }^{9}$ A. R. Zulhishamuddin, R. M. Suffian, S. N. Aqida, M. M. Rashidi, Microstructural evolution and phase transformation in laser cladding of $\mathrm{Cr}$ and Mo Powder on grey cast iron: mixture design of experiment (DOE), Mater. Res.-Ibero-Am. J., 21 (2018) 1, e20160560, doi:10.1590/1980-5373-MR-2016-0560

${ }^{10} \mathrm{D}$. Janicki, Microstructure and sliding wear behaviour of in-situ TiC-reinforced composite surface layers fabricated on ductile cast iron by laser alloying, Mater., 11 (2018) 1, 75, doi:10.3390/ ma11010075

${ }^{11}$ S. C. Tjong, Z. Y. Ma, Microstructural and mechanical characteristics of in situ metal matrix composites, Mat. Sci. Eng. R., 29 (2000), 49-113

${ }^{12}$ A. Lekatou, A. E. Karantzalis, A. Evangelou, V. Gousia, G. Kaptay, Z. Gacsi, P. Baumli, A. Simon, Aluminium reinforced by WC and TiC nanoparticles (ex-situ) and aluminide particles (in-situ): Microstructure, wear and corrosion behaviour, Mater. Design, 65 (2015), 1121-1135, doi:10.1016/j.matdes.2014.08.040

${ }^{13}$ H. Attar, M. Bönisch, M. Calin, L. C. Zhang, S. Scudino, J. Eckert, Selective laser melting of in situ titanium-titanium boride composites: Processing, microstructure and mechanical properties, Acta Mater., 76 (2014), 13-22, doi:10.1016/j.actamat.2014.05.022

${ }^{14}$ D. Janicki, Microstructural evolution during laser surface alloying of ductile cast iron with titanium, Arch. Metall. Mater., 62 (2017), 2425-2431, doi:10.1515/amm-2017-0357

${ }^{15}$ W. H. Tong, Z. L. Zhao, X. Y. Zhang, J. Wang, X. M. Guo, X. H. Duan, Y. Liu, Microstructure and properties of TiC/Co-Based alloy by laser cladding on the surface of nodular graphite cast iron, Acta Metall. Sin., 53 (2016), 472-478, doi:10.11900/0412.1961.2016. 00288

${ }^{16}$ Y. J. Li, S. Y. Dong, S. X. Yan, P. He, B. S. Xu, Phase evolution of ductile iron during laser cladding processing, Surf. Coat. Tech., 339 (2018), 37-47, doi:10.1016/j.surfcoat.2018.02.011

${ }^{17}$ Q. T. Li, Y. P. Lei, H. G. Fu, Growth mechanism, distribution characteristics and reinforcing behavior of $(\mathrm{Ti}, \mathrm{Nb}) \mathrm{C}$ particle in laser cladded Fe-based composite coating, Appl. Surf. Sci., 316 (2014), 610-616, doi:10.1016/j.apsusc.2014.08.052 